\title{
The Effect of Teaching English through Literature on Creative Writing at HSSC Level in Pakistan
}

\author{
Mamuna Ghani ${ }^{1} \&$ Muhammad Din $^{2}$ \\ ${ }^{1}$ The Islamia University of Bahawalpur, Pakistan \\ ${ }^{2}$ Government Postgraduate College Burewala, Pakistan \\ Correspondence: Muhammad Din, Government Postgraduate College Burewala, Pakistan. E-mail: \\ mduaau@gmail.com
}

Received: December 19, 2016 Accepted: January 10, 2017 Online Published: January 19, 2017

doi:10.5539/ijel.v7n2p142

URL: http://dx.doi.org/10.5539/ijel.v7n2p142

\begin{abstract}
Creative writing means the ESL/EFL learners' capacity to respond vividly and spontaneously, and to convey responses freely in their writing. This study brings to light the fact that teaching English through literature does not render any positive pay off in developing and honing the EFL/ESL learners' creative writing. In the Pakistani context, literature seems to be inadequate and improper language teaching tool at HSSC level. To achieve the set objectives of this study, the researcher went for the quantitative research methodology. So, a questionnaire comprising of 15 items encompassing the different aspects of creative writing was designed to collect data from 600 subjects (male/female) of intermediate level. The researcher also conducted an achievement test so that a correlation might be drawn between their attitude towards "developing creative writing through literature" and the score of their achievement test. The collected data were analyzed through software package (SPSS XX). The findings of this study explicitly reveal that the EFL learners remain unable to develop both the language skills (particularly writing skill) and language areas when they are taught English through literature. This study recommends that the teaching of English should be application oriented and task-based strategies and activities should be resorted to by the EL educators.
\end{abstract}

Keywords: creative writing, literature, ESL learners, language skill, activities

\section{Introduction}

Language is a universal characteristic of human beings. A language is a means of communication which is specific to a society. Thus, it becomes an integral part of the culture of that society. According to Hockett (1985), interchangeability, productivity, and cultural transmission are the features which characterize the human language. McArthur (1992) defines language as "a human system of communication which uses structured vocal sounds and can be embodied in other media such as writing, print, and physical signs". So, it can be said that language is a form of communication which is carried out through a system of symbols and these symbols are transmitted by vocal sounds. The language we use for the sake of communication is determined by the society in which we live and grow up and transmitted to us culturally as well. Whereas language learning arises from conscious knowledge of language gained through formal instruction. Yule (1996) has made an attempt to draw a distinction between these two concepts of language acquisition (LA) and language learning (LL) in some such a way as "the term acquisition, when used of language, refers to the gradual development of ability in a language by using it naturally in communicative situations; the term learning, however, applies to a conscious process of accumulating knowledge of the vocabulary and grammar of a language" (Yule, 1996, p. 191).

\subsection{Creative Writing}

Creative writing means an approach that emphasizes imaginative self-expression. It also means the ESL/EFL learners' capacity to respond vividly and spontaneously, and to convey responses freely in their writing. To express oneself well in writing and print also means creative writing. To the successful writers, it is a constant struggle to enjoy this competence. According to the experts (teachers and writers of manuals), there is no clear-cut criterion for establishing a scale of effectiveness in writing. However, they emphasize two levels of competence. They are as follows:

1) Ability with the basics of written language: spelling, punctuation, grammar, and word use. 
2) Awareness of the right style and rhetoric for the occasion and one's readership.

Apart from this, creative writing also means the skill which accomplishes the features like an effective address of the topic and task, well organized and well developed thought, clearly appropriate explanations, exemplifications and details. Unity, progression and coherence and consistent facility in the use of language also mark the salient features of the craft of creative writing. This skill also demands the demonstration of syntactic variety, appropriate word choice and word form and idiomaticity on the part of the ESL/EFL learners. According to Harris (1993), writing is a cognitive ability not an innate and natural one. It requires strenuous effort and training. O'Rourke (2005) styles it a craft and career. To Evernett (2005), creative writing means original composition. Harmer (2004) styles creative writing as the thinking, arranging, writing and revising the ideas. It is a well-established fact that creative writing is accorded a great importance when the EFL learners are taught English through literature but it has also been observed that these learners are not given adequate classroom practice in creative writing. To Brookes \&Marshal (2004) organization, planning and discovery of thoughts is creative writing. Sharples (1996) claims that "recreating emotional experiences freely in mind" is the essential philosophy of creative writing.

\subsection{Significance of English}

English has become an international language or an "international lingua franca". It has achieved such a status as is recognized by every country across the world. Yano (2001) finds a relation between globalization and the rise of English as a global language. Joseph (2004) also seconds this opinion regarding the global recognition of English language. Bozzini (2001) styles English an international language of remarkable sweep and diversity. Han (2005) also attributes the global significance of English language to the EFL learners' mounting awareness of the diverse cultures. Crystal (2003) claims English language is taught as a foreign language in more than one hundred countries. Moreover, in most of the countries, this language is used as an official or a "semi-official" language today. In Pakistan, English occupies a place of honor and prestige among the languages spoken here. In recent times, owing to the remarkable success of the English-speaking nations in the fields of industry and politics, the people, governments, and institutions have steered their focus and interest towards this language. Same is the case in Pakistan. It has generally been observed that strong language competence renders students good pedestal and they get entry into higher institutions as the learning of English language wields so much intense importance in Pakistan in the present scenario. English has also become the symbol of education and an elite status in the Pakistani society and has become the language of media, science, technology and a means of inter-national as well as intra-national communication. Ghani (2003) styles this language "a gateway to success" in Pakistan. Akram \& Mehmood (2007) have analyzed the factors which motivate the Pakistani students to go for the learning of English language. They claim that the motivational factors like studies abroad, greater job opportunities, social or missionary aspirations, better economic prospects and academic ends make them learn this language.

\subsection{Objectives}

The present study has the following objectives:

1) To unearth the facts regarding the role of literature as a teaching tool in developing EFL/ESL learners' skill of creative writing

2) To find out the problems faced by the students in learning and developing this craft through literature

3) To know the level of the ESL/EFL learners' language proficiency in creative writing

\subsection{Research Questions}

The present study strives to answer the following questions:

1) What is the role of literature as a teaching tool in developing EFL/ESL learners' skill of creative writing?

2) What are the problems faced by the students in learning and developing this craft through literature?

3) What is the level of the ESL/EFL learners' language proficiency in creative writing?

\section{Literature Review}

Giacomini (2015) advocates the use of new media "Storybird" in creative writing lessons and also describes the positive effects on the learners' writing process. She reflects that the employment of "storybird" as a teaching tool maximizes the learning opportunities through the learners' involvement. According to the researcher, this technological device also renders the learners not only a control of their learning experience but also an additional exposure to the language. 
Kunwar (2013) lays stress on creating opportunities for the interaction of the EFL learners with quality literature. While reflecting on the practices being carried on in Indian classrooms, the researcher presents a very saddening side of the picture regarding the use of literature in the language classroom. These facts also come true in the Pakistani context, too. While reflecting on the prevalent practice in the Indian context, Kunwar (2013) quite aptly maintains that a highly mechanical and conventional approach is adopted towards literature in the language classroom, teacher reads and explains each and every line the text, students are expected to scan the text so as to get information for the sake of the exam and they are expected to cram the answers to the questions given at the end of a lesson. Thus the basic aspects of language skills and language areas are neither dealt with nor developed because of this.

Adas \& Bakir (2013) claim that whenever the ESL learners write is class-room bound. According to the researchers, teaching method and environment, limited vocabulary, ill-structured sentences and the lack of feed-back are the causes which pose a formidable challenge in fostering the ESL learners' creative writing. They have also found out that the ESL learners develop their writing ability better when they are exposed to the online material.

Ammy Cummins (2009) explicates that rewriting or extending the literary texts fosters creative writing among the English language learners. She cites the term "reinventing" the works as a method of honing creative writing. The researcher also believes that creativity and storytelling are such cross-curricular skills as must be practiced in college courses.

Khan (2011) throws light on teaching writing in the Pakistani classrooms. The researcher points out that prescriptive curriculum, assessment system and the lack of teachers' professional autonomy reduce the Pakistani ESL learners' creativity. The researcher has also brought to light the negative wash back of the board examinations on the learners' developing creative writing in Pakistan.

Haider (2012) takes a review of major pedagogical trends and issues in teaching of writing. In this respect, the researcher maintains that the process of empowering the ESL learners in terms of linguistic enrichment is hampered because the FL educators are either unable or resistant. Literature based textbooks which are full of too much content and the evaluation system supplement the sad plight of teaching writing in English classrooms in Pakistan. The researcher also points out that the current model of writing is borrowed and has not been grown out of research and experiment.

Temizkan (2011) makes a decade wise survey regarding the contribution made towards the teaching of writing while exploring the effect of creative writing activities on the story writing skill. The researchers rounds off his study by saying that the needs of the present society can only be met by adopting such an educational approach as has an aim to develop creativity, inquisitiveness and critical thinking. The researcher also maintains that an educational setting should be organized in which the students can express their ideas freely.

\section{Research Methodology}

This study is primarily quantitative in nature. So, the researcher has gone for the quantitative research methodology. According to Dornyei (2011), "quantitative research involves data collection procedures that result primarily in numerical data which is then analyzed primarily by statistical methods." Typical example: survey research using a questionnaire, analyzed by statistical software such as SPSS.

\subsection{Participants and Research Tool}

The subjects of the present study are 600 (male and female) students of intermediate level of different colleges of Pakistan. For the administration of the questionnaire, such participants were selected as could prove the representative of the population of the study. For instance, the subjects of this study are the students of the intermediate class, part II. The research instrument consists of fifteen items and all the questionnaire items of this research instrument are close-ended on Likert scale from "strongly agree" to "strongly disagree". The research instrument designed for this study has been tried out in a pilot study so that its reliability and validity could be measured before its administration. The Alpha reliability of this questionnaire is calculated as .783 .

\subsection{Achievement Test}

In order to draw a correlation between the participants' attitude towards "teaching English through literature" and their achievement test score, the researcher has conducted an achievement test (TOEIC Writing Test). This achievement test primarily consisted of two questions i.e., the description of five pictures and writing an opinion essay. The achievement test carried 25 marks of which 15 were allocated to the first question and 10 to the second question. In order to convert the each respondent's obtained score into percentage, the researcher multiplied that score to the percentile i.e., 4 . 


\section{Results and Discussion}

After the data had been collected, it was fed into SPSS (XX) to get the mean score of the respondents' response and its standard deviation.

Table 1. ESL/EFL learners' response regarding the effect of teaching English through literature on creative writing

\begin{tabular}{|c|c|c|c|c|c|c|c|c|}
\hline S. No. & Questionnaire Items & SA & $\mathrm{A}$ & $\mathrm{N}$ & DA & SDA & Mean & SD \\
\hline 1 & The text books do not help me in my creative writing. & 135 & 305 & 7 & 137 & 16 & 3.68 & 1.135 \\
\hline 2 & $\begin{array}{l}\text { I find it difficult to render a satisfactory answer to a question } \\
\text { even when I have not crammed it. }\end{array}$ & 173 & 341 & 4 & 63 & 19 & 3.98 & 1.001 \\
\hline 3 & $\begin{array}{l}\text { When I am going through the text, I do not learn lexical } \\
\text { appropriateness. }\end{array}$ & 95 & 403 & 8 & 82 & 12 & 3.81 & .93 \\
\hline 4 & $\begin{array}{l}\text { I don't get a good deal of information about American and } \\
\text { British usage during my reading the text books. }\end{array}$ & 231 & 304 & 7 & 39 & 19 & 4.15 & .96 \\
\hline 5 & $\begin{array}{l}\text { While reading the literature, I do not get a chance to } \\
\text { improve and extend the use of communication strategies in } \\
\text { the language. }\end{array}$ & 134 & 345 & 12 & 96 & 13 & 3.82 & 1.023 \\
\hline 6 & $\begin{array}{l}\text { After preparing my lessons, I experience difficulty in } \\
\text { reading comprehension. }\end{array}$ & 45 & 292 & 4 & 220 & 39 & 3.14 & 1.182 \\
\hline 7 & $\begin{array}{l}\text { I can easily explain the given lines of a poem with reference } \\
\text { to the context. }\end{array}$ & 33 & 143 & 6 & 307 & 111 & 2.47 & 1.195 \\
\hline 8 & I can write the theme of a short story in my own words. & 39 & 248 & 7 & 243 & 63 & 2.93 & 1.223 \\
\hline 9 & $\begin{array}{l}\text { The teacher does not always encourage creative writing in } \\
\text { English class. }\end{array}$ & 70 & 284 & 19 & 204 & 23 & 3.29 & 1.163 \\
\hline 10 & $\begin{array}{l}\text { I can write a grammatically correct paragraph on any topic } \\
\text { given in the English class. }\end{array}$ & 20 & 107 & 5 & 341 & 127 & 2.25 & 1.082 \\
\hline 11 & $\begin{array}{l}\text { After having gone through the text, I cannot explain the } \\
\text { dialogues in my own words. }\end{array}$ & 66 & 334 & 5 & 172 & 23 & 3.41 & 1.128 \\
\hline 12 & $\begin{array}{l}\text { I cannot easily describe the different characters, scenes and } \\
\text { happenings which I come across in the text in my own } \\
\text { words. }\end{array}$ & 59 & 319 & 7 & 194 & 21 & 3.33 & 1.131 \\
\hline 13 & $\begin{array}{l}\text { To elaborate the literary terms in my own words is difficult } \\
\text { for me. }\end{array}$ & 91 & 381 & 6 & 111 & 11 & 3.72 & .994 \\
\hline 14 & $\begin{array}{l}\text { The language learnt through literature does not help me in } \\
\text { letter writing. }\end{array}$ & 89 & 328 & 11 & 154 & 18 & 3.53 & 1.114 \\
\hline 15 & $\begin{array}{l}\text { I can describe the summary of any poem or lesson in my } \\
\text { own words. }\end{array}$ & 27 & 193 & 8 & 275 & 97 & 2.63 & 1.213 \\
\hline
\end{tabular}

Table 1 shows the ESL/EFL learners' response and attitude regarding the role and effect of teaching English through literature on creative writing at HSSC level. It has been found out that teaching English through literature does not enable the students to write a letter or describe the summary of a poem or lesson or explain the dialogue in their own words just because of the memorization of the ready-made material. The present study finds out that the textbooks do not help the EFL learners develop creative writing as $83.3 \%$ subjects of the study maintain that they do not get any help from the textbooks in honing their art of creative writing. Adas \& Bakir (2013) have also rounded off their study that the mode of collaborative learning motivates them to read and write which results in the students' improved writing abilities. About $80 \%$ of the respondents claim that they do not get any chance to improve and extend the use of communication strategies in the target language when they are taught English through literature. It has also been discovered that the FL educator does not always encourage creative writing in English class. According to the collected data, 59\% respondents claim that creative writing is not encouraged in the language classroom. That's why the Pakistani EFL learners of intermediate level face problems when they have to do creative writing either in the classroom or in the examination hall. In this regard, Marashi \& Dadari (2012) maintain that task-based writing exercises a positive impact on the ESL learners' writing performance and creativity. The present study has also found out that $83 \%$ respondents claim that they do not learn lexical appropriateness while going through their textbooks. It has been found out that while EFL learners' being taught English through literature, 83\% cannot learn lexical appropriateness, $69.7 \%$ cannot explain the given lines of a poem with reference to the context, $77 \%$ remain unable to write a grammatically correct paragraph on any topic given in the English class, $66.7 \%$ cannot explain the dialogues in their own words, and 
$78.7 \%$ find themselves unable to elaborate the literary terms which they come across in their textbooks. Seyabi \& Tuzlukova (2014) have investigated the writing problems faced by the Omani school and university EFL learners. They have found that starting a paragraph, writing correct English sentence, putting ideas in a coherent way, choosing the appropriate lexical items and not having enough ideas about the given topic are the most problematic areas for the Omani learners of English.

Table 2. Correlation between achievement test and ESL learners' attitude towards creative writing

\begin{tabular}{lll} 
& Creative Writing & Achievement Test \\
\cline { 2 - 3 } Pearson Correlation & 1 & $-.740^{* *}$ \\
Sig. (2-tailed) & & .000 \\
$\mathrm{~N}$ & 600 \\
\hline
\end{tabular}

Note. ${ }^{* *}$. Correlation is significant at the 0.01 level (2-tailed).

The above result indicates that there is a negative correlation between Achievement Test and ESL/EFL learners' attitude towards creative writing. This shows that P-value is $<0.01$ level. This implies that the correlation was found statistically significant. The result reveals that the attitude of the learners does not affect their performance in English. Their language proficiency is satisfactory i.e., they have not shown any outstanding performance. The possible reasons behind this dichotomy between the ESL learners' attitude and performance can be sought in the fact that while their being taught English through literature the ESL learners are neither given chance for producing ideas nor any strategy for widening them. In addition to this, the EL educators do not encourage the learners of English language to study with their peer groups for generating ideas so that it may have a positive effect on their creative writing. Above all this, the motivating factors, involved in creative writing, like observation, thinking, exploration, innovation, knowledge and communicative strategies are not fostered in the English language classroom.

Table 3. Independent sample t-test (gender, location \& medium)

\begin{tabular}{|c|c|c|c|c|c|}
\hline Variable & & Mean & SD & Effect & Size \\
\hline \multirow[t]{6}{*}{ Creative Writing } & Gender & Male $(\mathrm{N}=304)$ & 50.91 & 5.388 & .019 \\
\hline & & Female $(\mathrm{N}=296)$ & 49.33 & 5.448 & \\
\hline & Location & Urban $(\mathrm{N}=305)$ & 50.09 & 5.384 & .002 \\
\hline & & Rural $(\mathrm{N}=295)$ & 50.17 & 5.569 & \\
\hline & Medium & English $(\mathrm{N}=303)$ & 50.48 & 5.289 & .003 \\
\hline & & Urdu $(\mathrm{N}=297)$ & 49.77 & 5.638 & \\
\hline
\end{tabular}

An Independent-Samples T Test was run to find out the relationship of creative writing with gender, location and medium. Table 3 shows that there is minor relationship between male and female students with reference to their learning creative writing through literature. The difference in the mean score of these two groups (male/female) is 1.58. The effect size of this relationship between them is also small i.e., .019 proves that there is no relationship between male and female students with reference to their learning the skill of creative writing through literature. It also shows that there is very little difference i.e., 0.92 in the mean score of urban and rural students with respect to creative writing. The effect size of the relationship between these two groups is small (.002) and this analysis proves there is no relationship between rural and urban students with reference to their learning creative writing through literature. A very slight difference $(0.71)$ has been noted in the mean score between the ESL learners who have English and Urdu medium of instruction. Thus, there is no relationship between medium of instruction (Urdu/English) and EFSL/EFL learners' language proficiency with respect to creative writing has been proved as here the effect size of their relationship is .003 which is of small level.

Table 4. Results of independent sample t-test (gender, location \& medium)

\begin{tabular}{llllllll}
\hline Achievement Test & Mean & SD & Std. E. M. & T Value & Sig. & Effect & Size \\
\hline Gender & Male $(\mathrm{N}=304)$ & 4.90 & 3.489 & .200 & -3.704 & .000 & .021 \\
& Female $(\mathrm{N}=296)$ & 5.94 & 3.394 & .197 & & & \\
\hline Location & Urban $(\mathrm{N}=305)$ & 5.19 & 3.687 & .211 & -1.635 & .102 & .003 \\
& Rural $(\mathrm{N}=295)$ & 5.65 & 3.239 & .189 & & & \\
\hline Medium & English $(\mathrm{N}=303)$ & 5.94 & 3.525 & .203 & 3.779 & .000 & .022 \\
& Urdu $(\mathrm{N}=297)$ & 4.88 & 3.353 & .195 & & & \\
\hline
\end{tabular}


Table 4 shows that the female students' mean score in the achievement test is higher than the male students'. It is 1.04 higher than those of the male students. The reason behind this difference is quite clear that the female students have more serious approach towards their assignments than the male students. So far as the ESL/EFL learners' location is concerned, there is some difference in the mean score of the urban and rural students. Here it reaches 0.46 in favor of the urban students. The justification behind this gap lies in the fact that in the Pakistani context urban students enjoy better educational provisions than the rural students. The mean score of English medium students in the achievement test falls at 5.94 whereas Urdu medium students' score is 4.88 . Table 4 shows the difference of 1.06 in the mean score between the achievement test and the medium of instruction of the ESL/EFL learners. This analysis highlights the fact that the students with English medium background outclass those students whose medium of instruction is Urdu because the English medium students have more exposure to this language than the Urdu medium learners. As a result, the level of their comprehension of the text, critical thinking and the way of expression is better than the Urdu medium students'.

The researcher has also categorized the respondents on the basis of the percentage of their score into six different grades i.e., exceptional, excellent, very good, good, fair and satisfactory so that an insight may be sought into role of literature in enhancing the ESL/EFL learners' competence of creative writing.

Table 5. Categories of ESL/EFL learners' level of creative writing proficiency

\begin{tabular}{lllll}
\hline & Categories & Frequency Percent & Valid Percent & Cumulative Percent \\
\hline Excellent & 4 & .7 & .7 & .7 \\
V. Good & 9 & 1.5 & 1.5 & 2.2 \\
Good & 18 & 3.0 & 3.0 & 5.2 \\
Fair & 28 & 4.7 & 4.7 & 9.8 \\
Satisfactory & 541 & 90.2 & 90.2 & 100.0 \\
\hline Total & 600 & 100.0 & 100.0 & \\
\hline
\end{tabular}

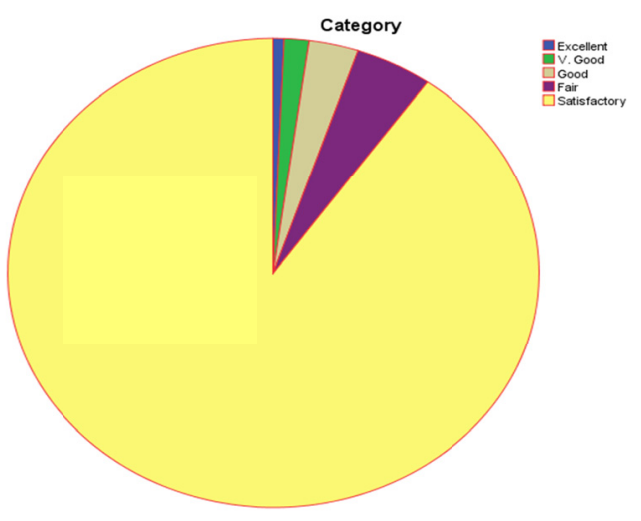

Figure 1. Categories of ESL/EFL learners' level of creative writing proficiency

Table 5 shows the level of the ESL learners' proficiency in creative writing. It has been found out that only .7\% percent of the learners fall in the "excellent" category while $1.5 \%$ of the ESL learners are very good and 3\% of them are good in this respect. The learners who fair in their creative writing are $4.7 \%$. The majority i.e., $90.2 \%$ of the ESL learners are those who have obtained below $40 \%$ marks in the achievement test of this study. This alarmingly low level of such a large number of the ESL learners' creative writing shows that the literature being taught to them does not help them develop their skill of creative writing. This study has unearthed the fact that the teaching of English through literature presented in the textbooks prescribed by the Punjab Textbook Board does not help the EFL learners of intermediate level to hone their craft of creative writing. For these Pakistani learners memorize those topics which are given in the examination. To this end, these EFL learners go for the guide books and ready-made material. These findings of the present study relate with those ones unearthed by the study conducted by Khan (2011) in which she maintains that "the Board Examination does not serve its purpose of assessing students' creativity".

This study also finds out that unmotivated approach of the faculty and students, curriculum and memorization are such factors as leave no room for creative writing in language class. That's why we find Cummins (2009) 
convinced of the role of a teacher in enhancing the EFL learners' skill of creative writing when he invites the college professors to integrate writing assignments into the curricula so that the EFL learners' skill in originality may be developed. Another study carried out by Siddiqui (2007) also seconds this opinion by saying that fixed syllabus, lack of resources, untrained teachers and large classes are the factors which go against the Pakistani EFL learners' developing and practicing creative writing. This study has also unearthed the fact that teaching English through "textbook-literature" enables the intermediate EFL learners neither to write uncrammed answers to a question taken from their textbook nor to improve their communicative strategies. For instance, $85.6 \%$ of the subjects of this study claim that they find it difficult to render a satisfactory answer to a question when they have not crammed it. This study brings to light the fact that the syllabus, the FL educators' approach towards creative writing, the EFL learners' hesitation and fear on embarking upon the task of creative writing and the examination system are the major obstacles in developing and sharpening the art of creative writing. The study conducted by Burges et al. (2002) also throws light on some of the challenges in enhancing the creative writing among the EFL learners. They opine that teachers' creativity and professional autonomy have been restrained by the prescriptive nature of curriculum and assessment system. The findings of the present study in analyzing the role of the textbooks in marring the EFL learners' creative writing relate with those of the study conducted by Mustafa (2009) which also opines that the textbooks do not provide the EFL learners a chance for building their skill, communication and expression when they are not taught through either of the approaches: genre and process. In this respect, Borden (2001), too, believes that the way writing is taught in Pakistan kills the EFL learners' creativity. The lack of enough ideas, choice of appropriate lexical items, organization and coherence are also those factors which pose a challenging hindrance in developing the skill of creative writing among the Pakistani ESL learners. An earlier study conducted by Chandio et al. (2013) has also analyzed the condition of creative writing in the Punjab (Pakistan) particularly North and South Punjab. They have found out the EFL learners' dissatisfactory condition of creative writing. While analyzing this sort of dissatisfactory condition, Adas \& Bakir (2013) round off their discussion that English language learners (ELLs) do not get a chance to do creative writing because they are mostly induced to do classroom-bound writing.

\section{Conclusion}

In Pakistan, not only is a paradigm shift required but the policy makers should also take radical decisions to develop the ESL learners' creative writing as there are many problems and challenges which render the textbooks an inadequate teaching resource. The most glaring among them are the prescriptive syllabus, teaching methodology, provision of ready-made material and the assessment system. Moreover, the selected textbooks are not used to develop and hone all the basic language skills-listening, speaking, reading and writing. For instance, the texts chosen to this end pose difficulties at grammatical, linguistic and literal level. It has also been observed that the teaching of English in Pakistan, specifically in state-run schools and colleges, is highly ritualized. The literary texts do not include the structures and vocabulary previously learned and difficult and ambiguous structures also elude most of the learners of English language. The texts chosen to teach English through literature rarely deal with linguistic and grammatical sides. The teaching of English through literature as second language looks to a given literary corpus answering, a grammar based on firm rules and concentrating on a relatively fixed canon of literary text, both as source and material and as model for composition.

\section{Suggestions}

The present study makes the suggestions as follows:

1) There must be separate classes for teaching writing skills.

2) The notion of blended learning should be resorted to by the EL educators.

3) A task-based approach should be used to enhance the ESL learners' creative writing.

4) The ESL learners should be motivated to open-ended questions so that they may regard mistakes a part of learning.

5) Modern teaching methodologies like communicative approach should be adapted in ELT classroom.

6) English language educators should encourage the students to write their ideas and share them with their class mates.

7) ESL educators should incorporate creative writing and self-analysis components into assignments.

8) English language teachers should read professional journals and attend professional meetings and faculty development workshops.

9) Process oriented paradigm of teaching writing should be resorted to. 


\section{References}

Adas, D., \& Bakir, A. (2013). Writing Difficulties and New Solutions: Blended Learning as an Approach to Improve Writing Abilities. International Journal of Humanities and Social Science, 3(9), 254-266.

Akram \& Mehmood (2009). The Status and Teaching of English in Pakistan. Language in India: Strength for Today and Bright Hope for Tomorrow, 7(12).

Boden, M. (2001). Creativity and Knowledge. In A. Craft, B. Seffrey, \& M. Liebling (Eds.), Creativity in Education. London: Continuum.

Bozzini, G. R., \& Leenerts, C. A. (Eds.) (2001). Literature without Borders: International Literature in English for Student Writers. Upper Saddle River, NJ: Prentice Hall.

Brrokes, I., \& Marshall, M. (2004). Good Writing Guide. New York: Harap Publishers Ltd.

Burgess et al. (2002). When the Hurly Burly's Done: What's Worth Fighting for in English in Education. Sheffield: National Association for Teaching of English.

Chandio et al. (2013). Condition of Creative Writing in the North and South Punjab. Pakistan Journal of Commerce and Social Sciences, 7(2), 321-330.

Crystal, D. (2003). English as a Global Language. Cambridge: Cambridge University Press. https://doi.org/10.1017/CBO9780511486999

Cummins, A. (2009). Tell Me a Story: Effective Use of Creative Writing Assignments in College Literature Courses. Currents in Teaching and Learning, 1(2), 42-49.

Dornyei, Z. (2011). Research Methods in Applied Linguistics: Qualitative, Quantitative and Mixed Methodologies. Oxford: Oxford University Press.

Evernett, N. (2005). Creative Writing and English. The Cambridge Quarterly, 34(3), 231-242. https://doi.org/10.1093/camqtly/bfi026

Ghani, M. (2003). The Status and Position of English Language in Pakistan. Journal of Social Sciences and Humanities, 1(1).

Giacomini, L. (2015). Using "Storybird" in Young Learners' Creative Writing Class. English Teaching Forum, 53(4), 35-39.

Haider, A. G. (2012). Teaching of Writing in Pakistan: A Review of Major Pedagogical Trends and Issues in Teaching of writing. Journal of Educational and Social Research, 2(3), 215-225.

Han, H. (2005). Cultivating Students' Intercultural Awareness through Literature in Language Teaching. Sino-US English Teaching (Serial No.21), 2(9), 73-76.

Harmer, J. (2004). How to Teach Writing (pp. 322-330). New Delhi: Pearson Longman.

Harris, J. (1993). Introducing Writing. London: Penguin Books Ltd.

Hockett, C. F. (1958). A Course in Modern Linguistics. Macmillan, 8(3-4), 73-75. https://doi.org/10.1111/j.1467-1770.1958.tb00870.x

Joseph, P. S. (2004). English in the Age of Globalization. Retrieved from http://www.geocities.com/jspark779/ENG420syllabus.pdf

Khan, H. I. (2011). Testing Creative Writing in Pakistan: Tensions and Potential in Classroom Practice. International Journal of Humanities and Social Science, 1(15) [Special Issue].

Kunwar, N. (2013). Literature in Classrooms: Practices and Reflection. FORTELL, 26, $20-22$.

Marashi, H., \& Dadari, L. (2012). The Impact of Using Task-based Writing on EFL Learners' Writing Performance and Creativity. Theory and Practice in Language Studies, 2(12), 2500-2507. https://doi.org/10.4304/tpls.2.12.2500-2507

McArthur, T. (1992). The Oxford Companion to the English Language. New York: Oxford University Press Inc.

Mustafa, S. (2009). The Importance of an Examining Board. Retrieved from http://www.education@dawn.com

O'Rourke, R. (2005). Creative Writing: Education, Culture and Community. Plymouth: Latimer Trend.

Seyabi1, F. A., \& Tuzlukova, V. (2014). Writing Problems and Strategies: An Investigative Study in the Omani School and University Context. Asian Journal of Social Sciences \& Humanities, 3(4), 37-48. 
Sharples, M. (1996). An Account of Writing as Creative Design, in the Science of Writing, Theories, Methods, Individual Differences and Applications. Mahwah, NJ: Erlbaum.

Siddiqui, S. (2007). Rethinking Education in Pakistan: Perceptions, Practices, and Possibilities. Lahore: Paramount Publishing Press.

Temizkan, M. (2011). The Effect of Creative Writing Activities on the Story Writing Skills. Educational Science: Theory and Practice, 11(1), 933-939.

Yano, Y. (2001). World Englishes in 2000 and Beyond. World Englishes, 20(2), 119-132. https://doi.org/10.1111/1467-971X.00204

Yule, G. (1996). The Study of Language. Cambridge: Cambridge University Press.

\section{Copyrights}

Copyright for this article is retained by the author(s), with first publication rights granted to the journal.

This is an open-access article distributed under the terms and conditions of the Creative Commons Attribution license (http://creativecommons.org/licenses/by/4.0/). 